\title{
Malignant melanomas of the nasal cavity after occupational exposure to formaldehyde
}

\author{
Mats Holmstrom, Valerie J Lund
}

\begin{abstract}
Formaldehyde is a well known nasal carcinogen in rodents, but so far there has been no convincing evidence that workers occupationally exposed to formaldehyde have an increased risk of nasal cancer. In this study three cases of malignant melanoma of the nasal mucosa in persons occupationally exposed to formaldehyde for a long time are presented. The occurrence of such a rare tumour in patients with significant exposure to a known carcinogen warrants further investigation.
\end{abstract}

Nasal cancer is an infrequent disease despite the nose being a contact organ for all inhaled substances. Nasal cancer in man has been linked with exposure to wood dust, nickel, and leather dust. ${ }^{1-3}$

Formaldehyde has been considered for the past few years as a risk factor for nasal cancer since it was shown that it is a potent carcinogen in rats exposed long term to high doses. ${ }^{4}$ Formaldehyde is a very reactive substance, causing single strand breaks with DNA and DNA protein cross links, ${ }^{5}$ and mutations in human cells in vitro. ${ }^{6}$

It is highly irritant to the upper respiratory tract in man and nasal symptoms are common in occupationally exposed workers, as are physiological disturbances of olfaction and nasomucociliary clearance. ${ }^{7}$ In workers occupationally exposed to formaldehyde, histological changes in nasal mucosa such as loss of cilia and metaplasia, have been reported $^{8}$; in one study dysplasia was also noted. ${ }^{9}$ No convincing evidence has accrued to show that formaldehyde is carcinogenic in man, however, despite several epidemiological studies. Two studies reported a correlation between formaldehyde and the occurrence of nasal cancer, ${ }^{1011}$ but others, in particular the mortality study of Blair $e t$ al on more than 26000 workers exposed to formaldehyde, did not. ${ }^{12}$ In the study of Walrath and Fraumeni on embalmers,

Professorial Unit, Institute of Laryngology and Otology, Royal National Throat, Nose, and Ear Hospital, Gray's Inn Road, London WC1X 8DA M Holmstrom, V J Lund persons with probably the highest occupational exposure, no correlation between formaldehyde exposure and nasal cancer was found, although mortality was significantly raised for cancer of the colon and of the skin (eight cases of skin cancer (four malignant melanomas) were found $v 3.6$ expected). ${ }^{13}$ Correlations between dermal malignant melanomas and extrinsic factors such as ultraviolet irradiation, ${ }^{14}$ polyvinyl chloride, ${ }^{15}$ polychlorinated biphenyls, ${ }^{16}$ and L-dopa ${ }^{17}$ have been reported.

In this study we describe three cases of malignant mucosal melanoma of the nasal cavity in patients who have been occupationally exposed to formaldehyde.

\section{Case reports}

CASE 1

A 58 year old woman presented with a large mass in the anterior left nasal cavity invading the vestibulum nasi and the soft tissue of the nasolabial fold. It was removed by a lateral rhinotomy approach. Histological examination showed invasive malignant melanoma (figure).

\section{History of exposure}

She had worked on a family chicken farm for five years between the ages of 18 and 23 and for the past five years, cleaning the broiler cabins. Thus she experienced a total of 10 years of exposure. The cabin cleaning was performed in the same way throughout

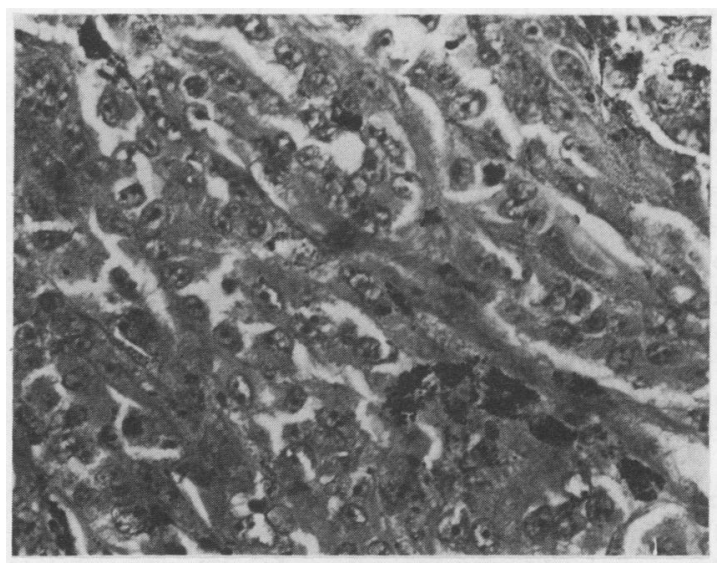

Photomicrograph of malignant melanoma taken from patient 1 showing collection of pigment. $H$ and $E \times 500$. (By kind permission of Professor L Michaels.) 
with a formaldehyde spray from a hand pump carried on her back. The cleaning, which occupied a full time week, took place at nine week intervals. Exposure to formaldehyde during the intervals was minimal. No protection was used when handling the formaldehyde. She was not exposed to other known carcinogens.

The patient complained of mild upper respiratory tract symptoms during exposure to formaldehyde, but she experienced no dermal symptoms or headache. Between 23 and 52 years of age she was a housewife and for seven years she worked as a domestic cleaner. During this time she also occasionally helped with cleaning the broiler cabins.

\section{CASE 2}

A 59 year old man was referred with a blockage of the right nostril from which a red fleshy polypoidal mass was subsequently removed by a lateral rhinotomy approach. Histological examination showed an amelanotic melanoma.

\section{History of exposure}

This patient was employed for 12 years as a pathology assistant in a histology department, making museum preparations and thus having daily exposure to formaldehyde. He was subsequently employed for seven years as a laboratory assistant in the chemical industry where he was exposed to formaldehyde, chloroform, benzene, and mercuric chloride. He then returned to the post of pathology technician and has remained there since (18 years) with daily exposure to formaldehyde. The department also had constant ventilation problems with an air recirculation and filtration system.

In total he has been occupationally exposed to formaldehyde for 37 years. During exposure he experienced epiphora or smarting of the eyes and nasal obstruction and during peaks of exposure he also complained of nasal discharge. Neither headache nor dermal problems were reported.

\section{CASE 3}

A 67 year old man was referred after a right side nasal polypectomy. Histological examination had suggested an anaplastic carcinoma for which an initial course of radiotherapy had been given. A lateral rhinotomy, later extended to a craniofacial resection was performed and histological examination showed a non-pigmented malignant melonoma. This was compatible with the material obtained from the original polypectomy.

\section{History of exposure}

After nine years in the army, this patient worked for 40 years in building construction. His job was mainly to fill cavities in houses with an insulation material containing urea formaldehyde, which was pumped into the walls. This was carried out both indoors and outside. During exposure to formaldehyde his eyes were irritated and he experienced a sore throat and pricking and itching of the skin. No nasal problems were reported.

\section{Discussion}

As the nose comes into contact with all inhaled substances, it is probable that local defence mechanisms are responsible for the rarity of nasal cancer compared with malignancy in the rest of the respiratory tract. From animal studies it is known that formaldehyde causes ciliastasis in the anterior part of the nose $\mathrm{e}^{18}$ and loss of cilia and metaplasia in this region if exposure is continued. ${ }^{19}$ This deterioration in mucociliary function is probably an important factor in carcinogenesis. After long term and high dose exposure (15 ppm) to formaldehyde cancer occurs in $50 \%$ of exposed rats. In man a dose dependent deterioration in mucociliary function due to exposure to formaldehyde has been shown by Andersen and Mølhave ${ }^{20}$ and a significant reduction in mucociliary clearance time has been found in workers occupationally exposed to formaldehyde. ${ }^{7}$

It has been estimated that exposure to doses of formaldehyde under $1 \mathrm{ppm}$ is not associated with cancer risk in $\operatorname{man}^{21}$ and currently mean exposure values above this concentration are rare in industrialised countries. ${ }^{22}$

In this report three cases of malignant melanoma of the nasal mucosa are described. This is a rare tumour $^{22}$ that has not, to our knowledge, been reported before in workers exposed to formaldehyde, although Walrath and Fraumeni described an increased incidence of cutaneous melanomas in their study of embalmers. ${ }^{13}$

It has not been possible to measure the concentrations of formaldehyde, or other chemicals exposed to, for any of the cases presented but the histories suggest that all three had experienced high peak concentrations of formaldehyde and a long exposure.

Risk factors due to exposures to other chemicals were apparently not present. Also, the families had no histories of melanomas, a factor that has been reported to be significant. ${ }^{23}$ No other manifestations of cutaneous or mucosal malignant melanomas were found.

Discussion concerning the aetiology of malignant melanomas has mainly centred on the effect of sunshine, but several reports exist of increased incidence of malignant melanomas in occupational groups such as workers in the telecommunications industry $^{24}$ and in various chemical industries. ${ }^{25-28}$ Certain chemicals have been linked to the induction of melanomas-for example, 7, 12-dimethyl benzanthracene in tests on Syrian golden hamsters ${ }^{29}$ and $\mathrm{PCB}^{16}$ and $\mathrm{L}$-dopa ${ }^{17}$ in epidemiological studies. 
The epidemiological link between formaldehyde and nasal cancer is not yet proved but when considering such a rare disease in patients with significant exposure to a known carcinogen, the apparent association warrants documentation and further investigation.

Requests for reprints to: Dr V J Lund, MS, FRCS.

1 Acheson ED, Cowdell RH, Hadfield EH, Macbeth RG. Nasal cancer in woodworkers in the furniture industry. $\mathrm{Br} \mathrm{Med} \mathrm{J}$ 1968;2:587-96.

2 Torjussen W, Solberg LA, Högetveit AC. Histopathological changes of the nasal mucosa in active and retired nickel workers. Br J Cancer 1970;40:568-80.

3 Acheson ED, Cowdell RH, Jolles B. Nasal cancer in the Northamptonshire boot and shoe industry. $\mathrm{Br}$ Med $J$ 1970;1:385-93.

4 Kerns WD, Pavkov KL, Donofrio DJ, Gralla EJ, Swenberg JA. Carcinogenicity of formaldehyde in rats and mice after longterm inhalation exposure. Cancer Res 1983;43:4382-92.

5 Saladino AJ, Willey JC, Lechner JF, Grafström RC, LaVeck M, Harris CC. Effects of formaldehyde, acetaldehyde, benzyl peroxide and hydrogen peroxide on cultured human bronchial epithelial cells. Cancer Res 1985;45:2522-6.

6 Goldmacher VS, Thilly WG. Formaldehyde is mutagenic for cultured human cells. Mutat Res 1983;116:417-22.

7 Holmström M, Wilhelmsson B. Respiratory symptoms and pathophysiological effects of occupational exposure to formaldehyde and wood dust. Scand $J$ Work Environ Health 1988;14:306-11.

8 Holmström M, Wilhelmsson B, Hellquist H, Rosen G. Histological changes in the nasal mucosa in persons occupationally exposed to formaldehyde alone and in combination with wood dust. Acta Otolaryngol (Stockh) 1989;107:120-9.

9 Boysen M, Zadig E, Digernes V, Abeler V, Reith A. Nasal mucosa in workers exposed to formaldehyde: a pilot study. $\mathrm{Br}$ $J$ Ind Med 1990;47:116-21.

10 Olsen JH, Plough Jensen S, Hink M, Faurbo K, Breum NO, Moller Jensen O. Occupational formaldehyde exposure and increased cancer risk in man. Int J Cancer 1984;34:639-44.

11 Hayes RB, Raatgever JW, Bruyn de A, Gerin M. Cancer of the nasal cavity and paranasal sinuses and formaldehyde exposure. Int $J$ Cancer 1986;37:487-92.

12 Blair A, Stewart $\mathrm{P}, \mathrm{O}^{\prime} \mathrm{Berg} \mathrm{M}$, et al. Mortality among industrial workers exposed to formaldehyde. J Natl Cancer Inst 1986;76:1071-84.
13 Walrath J, Fraumeni JF Jr. Mortality patterns among embalmers. Int J Cancer 1983;31:407-11.

14 Holman CDJ, Armstrong BK. Cutaneous malignant melanoma and indicators of total accumulated exposure to the sun. An analysis separating histogenic types. J Natl Cancer Inst 1984;73:75-82.

15 Heldaas SS, Andersen A, Langård S. Incidence of cancer among vinyl chloride and polyvinyl chloride workers; a further evidence for an association with malignant melanoma. $\mathrm{Br} J$ Ind Med 1987;44:278-80.

16 Bahn AK, Rosenwaike I, Herrmann N, Grover P, Stellman J, O'Leary K. Melanoma after exposure to PCBs. N Engl J Med 1976;295:450.

17 Fermaglich J, Delaney P. Parkinson's disease, melanoma, and levodopa. J Neurol 1977;215:221-4.

18 Morgan KT, Pattersson DL, Gross EA. Response of the mucociliary apparatus of F-344 rats to formaldehyde gas. Toxicol Appl Pharmacol 1986;82:1-13.

19 Holmström M, Wilhelmsson B, Hellquist H. Histological changes in the nasal mucosa in rats after long-term exposure to formaldehyde and wood dust. Acta Otolaryngol (Stockh) 1989;108:274-84.

20 Andersen I, Mølhave L. Controlled human studies with formaldehyde. In: Gibson JE, ed. Formaldehyde toxicity. Washington DC: Hemisphere Publishing Corporation, 1983:154-65.

21 Rosén G, Bergström B, Ekholm U. Occupational exposure to formaldehyde in Sweden. Arbete och Hälsa 1984;50:1-25. (In Swedish.)

22 Lund VJ. Malignant melanoma of the nasal cavity and paranasal sinuses. $J$ Laryngol Otol 1982;96:347-55.

23 Holman CDJ, Armstrong BK. Pigmentary traits, ethnic origin benign nevi, and familial history as risk factors for cutaneous malignant melanoma. $J$ Natl Cancer Inst 1984;72:257-66.

24 De Guire L, Theriault G, Iturra H, Provencher S, Cyr D, Case $\mathrm{BW}$. Increased incidence of malignant melanoma of the skin in workers in a telecommunications industry. $\mathrm{Br} J$ Ind Med 1988;45:824-8.

25 Hoar SH, Pell S. A retrospective cohort study of mortality and cancer incidence among chemists. J Occup Med 1981;23: 485-94.

26 Pell S, O'Berg M, Karrh BW. Cancer epidemiologic surveillance in the Du Pont Company. J Occup Med 1978;20:725-40.

27 Thomas TL, Decoufle P. Mortality among workers employed in the pharmaceutical industry: a preliminary investigation. J Occup Med 1979;21:619-23.

28 Wright WE, Peters JM, Mack TM. Organic chemicals and malignant melanoma. Am J Ind Med 1983;4:577-81.

29 Goerttler K, Loehrke H, Schweizer J, Hesse B. Two-stage tumorigenesis of dermal melanocytes in the back skin of Syrian Golden hamster using systemic initiation with 7,12dimethylbenz[a]anthracene and topical promotion with 12-Otetradecanoylphorbol-13-acetate. Cancer Res 1980;40:155-61.

Accepted 6 August 1990 